\title{
Robotic versus open and video-assisted thoracoscopic surgery approaches for lobectomy
}

\author{
François Montagne ${ }^{1}$, Benjamin Bottet ${ }^{1}$, Matthieu Sarsam¹, Frankie Mbadinga ${ }^{1}$, Zied Chaari ${ }^{1,2}$, Philippe \\ Rinieri', Jean Melki ${ }^{1}$, Christophe Peillon' ${ }^{1}$ Jean-Marc Baste ${ }^{3}$ \\ 'Department of General Thoracic Surgery, Rouen University Hospital, Rouen 76000, France. \\ 2Department of Thoracic and Cardiovascular Surgery, Habib Bourguiba University Hospital, Sfax 3029, Tunisie. \\ ${ }^{3}$ Normandie University, UNIROUEN, INSERM U1096, Department of General Thoracic Surgery, Rouen University Hospital, \\ Rouen 76000, France.
}

Correspondence to: Dr. François Montagne, Department of General Thoracic Surgery, Rouen University Hospital, 1 rue de Germont, Rouen 76000,France. E-mail: francois.montagne0438@orange.fr

How to cite this article: Montagne F, Bottet B, Sarsam M, Mbadinga F, Chaari Z, Rinieri P, Melki J, Peillon C, Baste JM. Robotic
versus open and video-assisted thoracoscopic surgery approaches for lobectomy. Mini-invasive Surg 2020;4:17. http://dx.doi.org/10.20517/2574-1225.2019.74

Received: 30 Dec 2019 First Decision: 24 Jan 2020 Revised: 3 Feb 2020 Accepted: 6 Feb 2020 Published: 11 Mar 2020

Science Editor: Valérie Lacroix Copy Editor: Jing-Wen Zhang Production Editor: Jing Yu

\begin{abstract}
More and more data are available on the benefits of minimally invasive thoracic surgery compared to open thoracic surgery in the curative treatment of early-stage non-small cell lung cancer. However, results are conflicting, especially when video-assisted thoracoscopic surgery (VATS) is compared to robotic-assisted thoracoscopic surgery (RATS) for lobectomy. Our goal is to report the main results of recent systematic reviews and meta-analyses comparing RATS, VATS, and open surgery for lobectomy. Using PubMed database, we selected systematic reviews and meta-analyses, which compared the short-term outcomes of patients treated by RATS, VATS, or open surgery for lobectomy. In all but one of the systematic reviews, robotic lobectomy allowed similar short-term outcomes as VATS lobectomy and better short-term outcomes than open surgery. One meta-analysis by O'Sullivan et al. found that robotic lobectomy was associated with fewer adverse events $(P<0.00001)$ and lower 30 -day mortality $(P=0.001)$, compared to VATS lobectomy. Robotic lobectomy could be a valid alternative to VATS and open lobectomy. Shortterm outcomes do not appear to be different between VATS and RATS cohorts, except in one recent meta-analysis, which reported the superiority of RATS compared to VATS. Without cost analysis and randomized controlled trials with long-term outcomes, no strong conclusions can be drawn.
\end{abstract}

Keywords: Minimally invasive surgery, robotic surgery, robotic-assisted thoracoscopic surgery, video-assisted thoracoscopic surgery, lobectomy, lung cancer, short-term outcomes, review

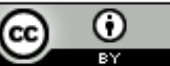

(C) The Author(s) 2020. Open Access This article is licensed under a Creative Commons Attribution 4.0 International License (https://creativecommons.org/licenses/by/4.0/), which permits unrestricted use, sharing, adaptation, distribution and reproduction in any medium or format, for any purpose, even commercially, as long as you give appropriate credit to the original author(s) and the source, provide a link to the Creative Commons license, and indicate if changes were made.

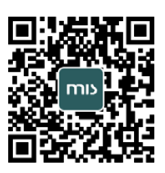




\section{INTRODUCTION}

Surgery is the cornerstone of early stage non-small cell lung cancer (NSCLC) treatment, and lobectomy is currently the preferred type of lung resection for clinical stages I and II of NSCLC ${ }^{[1]}$. Minimally invasive approaches, namely video-assisted thoracoscopic surgery (VATS) and robotic-assisted thoracoscopic surgery (RATS), are preferred for early stage NSCLC, and are even recommended for those early stage NSCLC $^{[2]}$. Robotic thoracic surgery has developed rapidly since the first publication by Melfi et al ${ }^{[3]}$ in 2002, which reported the first cases of robotic thoracic procedures including five lobectomies.

Thoracic surgery approaches have evolved during the last two decades, as has the way of performing lung lobectomy, but not its goal. Lobectomy for NSCLC involves two steps, namely lung resection and complete lymph node resection, according to international recommendations ${ }^{[1,4-12]}$. Minimally invasive surgery provides better short-term outcomes compared to open surgery, with fewer adverse events and shorter length of hospital stay ${ }^{[13-15]}$. Until recently, many systematic reviews with meta-analyses and large retrospective databases comparing VATS and RATS lobectomy have provided conflicting results regarding short-term outcomes.

Our goal in this mini-review is to report the main results of recent systematic reviews and meta-analyses comparing the short-term outcomes of patients treated by RATS, VATS, or open surgery for lobectomy.

\section{METHODS}

PubMed and Web of Science were searched to identify potentially eligible literature up to 1 October 2019 reporting lobectomy performed by open surgery, VATS, or RATS and to collect data on the shortterm outcomes of patients according to each surgical approach. The search items were: "video-assisted thoracoscopic surgery" OR "VATS", "robotic-assisted thoracoscopic surgery" OR "RATS", "thoracotomy", "lobectomy", "lung cancer", "techniques", "systematic review" AND "meta-analysis", AND "national database". Only articles in English language were included.

\section{RESULTS}

\section{Performing lobectomy: common points and differences between RATS, VATS, and open thoracotomy}

With the advent and the spread of minimally invasive surgery, such as VATS and RATS, the use of open thoracotomy as the "gold standard approach" has decreased. Thoracotomy includes two approaches: anterolateral thoracotomy and posterolateral thoracotomy. With both approaches, whenever possible, a muscle sparing incision is made. To perform lobectomy for NSCLC, a hilar dissection or a fissureless technique is used. Mediastinal lymph node dissection is done before or after lobectomy. Thoracotomy is still the main approach to perform lobectomy for early stage NSCLC: between 2010 and 2012, 67\% of lobectomies were performed by open thoracotomy, $26 \%$ by VATS, and $7 \%$ by RATS, as registered in the USA nationwide cancer database ${ }^{[16]}$.

VATS for early stage NSCLC is now well accepted, with better short-term outcomes ${ }^{[17,18]}$ [Table 1]. With VATS, a fissureless technique is preferred and mediastinal lymph node dissection is done at the end of the procedure. Despite the benefits associated with VATS lobectomy, this approach is not universally used for many reasons. The main reason is the technical difficulty in performing complete hilar, lobar, interlobar, and mediastinal lymph node resection ${ }^{[19]}$ according to international recommendations.

RATS offers some advantages compared to VATS. First, structures are magnified with a stable, highquality $3 \mathrm{D}$ optical instrument directed by the surgeon and not by the surgeon's assistant. Instruments have up to seven degrees of freedom due to the Endowrist system. With RATS, lobectomy adheres to oncologic 
Table 1. Main reports concerning short-term outcomes after lobectomy performed by thoracotomy or a minimally invasive approach as VATS or RATS for a NSCLC in studies used for this article

\begin{tabular}{|c|c|c|c|}
\hline Ref. & Population study & Outcomes & Results \\
\hline Nget al..$^{[13]}$ & $\begin{array}{l}\text { Comparison of multiport and } \\
\text { uniport VATS and RATS } 145 \\
\text { studies, } 369,793 \text { patients } \\
\text { Comparison of VATS to } \\
\text { Open: } 115 \text { studies }\end{array}$ & $\begin{array}{l}\text { VATS vs. Open } \\
\text { Nodal upstaging } \\
\text { Complications } \\
\text { 90-day mortality } \\
\text { Length of hospital stay } \\
\text { 5-year OS } \\
\text { 5-year DFS } \\
\text { VATS vs. RATS } \\
\text { Nodal upstaging } \\
\text { Complications } \\
\text { 30-day mortality } \\
\text { Length of hospital stay } \\
\text { 5-year OS } \\
\text { 5-year DFS }\end{array}$ & $\begin{array}{l}\text { OR } 0.71(95 \% \mathrm{Cl} 0.58-0.87) P<0.001 \\
\text { OR } 0.64(95 \% \mathrm{Cl} 0.59-0.71) P<0.001 \\
\text { OR } 0.78(95 \% \mathrm{Cl} 0.56-1.07) P=0.12 \\
-1.9 \mathrm{~d}(95 \% \mathrm{Cl}-2.25 \text { to }-1.54) P<0.001 \\
\text { OR } 1.35(95 \% \mathrm{Cl} 1.17-1.56) P<0.0001 \\
\text { OR } 1.15(95 \% \mathrm{Cl} 0.94-1.4) P=0.18 \\
\text { OR } 1.02(95 \% \mathrm{Cl} 0.85-1.22) P=0.87 \\
\text { OR } 1.28(95 \% \mathrm{Cl} 0.75-2.17) P=0.37 \\
\text { OR } 1.04(95 \% \mathrm{Cl} 0.73-1.47) P=0.85 \\
\text {-O.16 d }(95 \% \mathrm{Cl}-0.81 \text { to }-0.48) P=0.62 \\
\text { OR } 0.79(95 \% \mathrm{Cl} 0.47-1.33) P=0.38 \\
\text { OR } 0.71(95 \% \mathrm{Cl} 0.44-1.14) P=0.16\end{array}$ \\
\hline O'Sullivan et al. ${ }^{[14]}$ & $\begin{array}{l}\text { Comparison of short-term } \\
\text { outcomes after lobectomy } \\
\text { performed by Open. VATS or } \\
\text { RATS } 112,356 \text { patients }\end{array}$ & $\begin{array}{l}\text { RATS vs. Open } \\
\text { Complications } \\
\text { 30-day mortality } \\
\text { Length of hospital stay } \\
\text { Operative time } \\
\text { RATS vs. VATS } \\
\text { 30-day mortality } \\
\text { Operative time }\end{array}$ & $\begin{array}{l}\text { OR } 0.67(95 \% \mathrm{Cl} 0.58-0.76) P<0.00001 \\
\text { O.53 }(95 \% \mathrm{Cl} 0.33-0.85) P=0.08 \\
\text { WMD }-1.4(95 \% \mathrm{Cl}-1.96 \text { to }-0.85) P<0.00001 \\
\text { WMD } 65.56(95 \% \mathrm{Cl} 53.66-77.46) P<0.00001 \\
\text { OR } 0.61(95 \% \mathrm{Cl} 0.45-0.83) P=0.001 \\
\text { WMD } 4.98(95 \% \mathrm{Cl} 2.61-7.36) P<0.001\end{array}$ \\
\hline Adams et al. ${ }^{[29]}$ & $\begin{array}{l}\text { Comparison of short-term } \\
\text { outcomes after a lobectomy } \\
\text { RATS to VATS and Open in a } \\
\text { national Database } \\
n=116 \text { RATS } \\
n=4612 \text { VATS } \\
n=5913 \text { Open }\end{array}$ & $\begin{array}{l}\text { RATS vs. Open } \\
\text { Operative time } \\
\text { Postoperative blood transfusion } \\
\text { Air leak }>5 \text { days } \\
\text { Chest tube duration } \\
\text { Length of hospital stay } \\
\text { 30-day mortality } \\
\text { RATS vs. VATS } \\
\text { Operative time } \\
\text { Postoperative blood transfusion } \\
\text { Air leak }>5 \text { days } \\
\text { Chest tube duration } \\
\text { Length of hospital stay } \\
\text { 30-day mortality }\end{array}$ & $\begin{array}{l}241 \min v s .175 \min , P<0.001 \\
0.9 \% \text { vs. } 7.8 \%, P=0.002 \text { in } \% \text { of patient } \\
5.2 \% \text { vs. } 10.8 \%, P=0.05 \\
3.2 \text { days } v s .4 .8 \text { days, } P<0.001 \\
4.7 \text { days } v s .7 .3 \text { days, } P<0.001 \text { in median } \\
0 \% \text { vs. } 2.2 \%, P=0.18 \\
241 \text { min vs. } 179 \text { min, } P<0.001 \\
0.9 \% \text { vs. } 3.8 \%, P=0.13 \text { in } \% \text { of patient } \\
5.2 \% \text { vs. } 8.9 \%, P=0.17 \\
3.2 \text { days } v s .3 .7 \text { days, } P=0.18 \\
4.7 \text { days } v s .5 .3 \text { days, } P=0.07 \\
0 \% \text { vs. } 1 \%, P=0.63\end{array}$ \\
\hline Agzarian et al. ${ }^{[30]}$ & $\begin{array}{l}\text { Comparison of short-term } \\
\text { outcomes after a lobectomy } \\
\text { RATS to VATS and Open } 20 \\
\text { articles }\end{array}$ & $\begin{array}{l}\text { RATS vs. Open } \\
\text { Operative time } \\
\text { Length of hospital stay } \\
\text { RATS vs. VATS } \\
\text { Operative time } \\
\text { Length of hospital stay }\end{array}$ & $\begin{array}{l}\text { WMD } 40.10(95 \% \mathrm{Cl}-50.76 \text { to }-130.96) P=0.39 \\
-1.97 \text { days }(95 \% \mathrm{Cl}-4.05 \text { to }-0.1) P=0.06 \text { in median } \\
\text { WMD } 64.28(95 \% \mathrm{Cl}-50.35 \text { to }-178.91) P=0.27 \\
-0.68 \text { days }(95 \% \mathrm{Cl}-1.52 \text { to }-0.16) P=0.11\end{array}$ \\
\hline Kent et al. ${ }^{[15]}$ & $\begin{array}{l}\text { Comparison of short-term } \\
\text { outcomes after a lobectomy } \\
\text { RATS to VATS and Open in a } \\
\text { national database } \\
n=411 \text { RATS } \\
n=1233 \text { VATS } \\
n=1233 \text { Open for } \\
\text { propensity-matched analysis }\end{array}$ & $\begin{array}{l}\text { RATS vs. Open } \\
\text { Complication rate } \\
\text { Mortality rate } \\
\text { Length of hospital stay } \\
\text { RATS vs. VATS } \\
\text { Complication rate } \\
\text { Mortality } \\
\text { Length of stay }\end{array}$ & 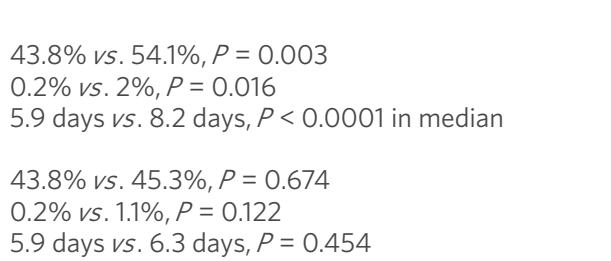 \\
\hline Rajaram et al. ${ }^{[31]}$ & $\begin{array}{l}\text { Comparison of short-term } \\
\text { outcomes after a lobectomy } \\
\text { RATS to VATS and Open in a } \\
\text { national database } \\
n=3238 \text { to } 3689 \text { RATS } \\
n=3401 \text { to } 3689 \text { VATS } \\
n=3405 \text { to } 3689 \text { Open for } \\
\text { propensity-matched analysis }\end{array}$ & $\begin{array}{l}\text { RATS vs. Open } \\
\text { Length of hospital stay } \\
\text { 90-day Mortality } \\
\text { 30-day unplanned readmission } \\
\text { RATS vs. VATS } \\
\text { Length of hospital stay } \\
\text { 90-day Mortality } \\
\text { 30-day unplanned readmission }\end{array}$ & $\begin{array}{l}6.1 \text { days vs. } 5.7 \text { days, } P<0.001 \text { in median } \\
3 \% \text { vs. } 3.4 \%, P=0.097 \\
4.1 \% \text { vs. } 4 \%, P=0.81 \\
6.1 \text { days vs. } 5.9 \text { days, } P=0.019 \text { in median } \\
3 \% \text { vs. } 2.8 \%, P=0.877 \\
4.1 \% \text { vs. } 4.6 \%, P=0.258\end{array}$ \\
\hline Cao et al. ${ }^{[32]}$ & $\begin{array}{l}\text { Comparison of short and } \\
\text { long term outcomes after a } \\
\text { lobectomy RATS and VATS } n \\
=941 \text { patients } \\
\text { For meta-analysis for short- } \\
\text { term outcomes } n=160 \text { RATS } \\
\text { and } n=372 \text { Open }\end{array}$ & $\begin{array}{l}\text { RATS vs. Open } \\
\text { Complication rate } \\
\text { Length of hospital stay }\end{array}$ & $\begin{array}{l}\text { RR } 0.77(95 \% \mathrm{Cl} 0.54-1.09) P=0.14 \\
\text { Shorter in RATS group } P<0.05\end{array}$ \\
\hline
\end{tabular}




\begin{tabular}{|c|c|c|c|}
\hline Paul et al. ${ }^{[33]}$ & $\begin{array}{l}\text { Comparison of short-term } \\
\text { outcomes after a lobectomy } \\
\text { RATS and VATS in a sample } \\
\text { of a nationwide database } \\
n=2498 \text { RATS } \\
n=37,595 \text { VATS }\end{array}$ & $\begin{array}{l}\text { RATS vs. VATS } \\
\text { Length of hospital stay } \\
\text { Complication rate } \\
\text { In-Hospital mortality } \\
\text { Total Costs }\end{array}$ & $\begin{array}{l}5 \text { days } v s .5 \text { days, } P=0.23 \text { in median } \\
50.1 \% \text { vs. } 45.2 \%, P=0.32 \\
0.7 \% \text { vs. } 1.3 \%, P=0.15 \\
22.582 \$ \text { vs. } 17.874 \$ P<0.001 \text { (Median) }\end{array}$ \\
\hline Emmert et al. ${ }^{[35]}$ & $\begin{array}{l}\text { Comparison of short-term } \\
\text { outcomes after a lobectomy } \\
\text { RATS and VATS } \\
n=3758 \text { RATS } \\
n=58,677 \text { VATS }\end{array}$ & $\begin{array}{l}\text { RATS vs. VATS } \\
\text { Length of hospital stay } \\
\text { Operative time } \\
\text { Chest tube duration } \\
\text { Mortality }\end{array}$ & $\begin{array}{l}-1.08 \text { days }(95 \% \mathrm{Cl}-2.33 \text { to }-0.17) P=0.078 \text { mean } \\
\text { difference } \\
8.97 \text { min }(95 \% \mathrm{Cl}-28.12 \text { to }-46.07) P=0.56 \text { mean } \\
\text { difference } \\
-0.71 \text { days }(95 \% \mathrm{Cl}-1.5 \text { to }-0.1) P=0.064 \text { mean } \\
\text { difference } \\
\text { OR } 0.52(95 \% \mathrm{Cl} 0.29-0.93)\end{array}$ \\
\hline Louie et al. ${ }^{[34]}$ & $\begin{array}{l}\text { Comparison of short term } \\
\text { outcomes after a lobectomy } \\
\text { RATS and VATS } \\
n=1220 \text { RATS } \\
n=12,378 \text { VATS } \\
\text { National Database }\end{array}$ & $\begin{array}{l}\text { RATS } v s \text {. VATS } \\
\text { Operative time } \\
\text { Air Leak }>5 \text { days } \\
\text { Length of hospital stay }<4 \text { days } \\
\text { 30-day mortality }\end{array}$ & $\begin{array}{l}186 \min v s .173 \min P<0.001 \\
10 \% \text { vs. } 9.8 \% P=0.8135 \\
48 \% \text { vs. } 39 \% P<0.001 \\
0.6 \% \text { vs. } 0.8 \% P=0.4\end{array}$ \\
\hline Wei et $a{ }^{[36]}$ & $\begin{array}{l}\text { Comparison of short-term } \\
\text { outcomes after a lobectomy } \\
\text { RATS and VATS } \\
n=4727 \text { RATS } \\
n=56,232 \text { VATS before } \\
\text { matched analysis }\end{array}$ & $\begin{array}{l}\text { RATS } v s \text {. VATS for matched } \\
\text { cohort } \\
\text { 30-day mortality } \\
\text { Postoperative morbidity }\end{array}$ & $\begin{array}{l}\text { RR } 0.12(95 \% \mathrm{Cl} 0.01-1.07) P=0.06 \\
\text { RR } 0.95(95 \% \mathrm{Cl} 0.83-1.08) P=0.41\end{array}$ \\
\hline
\end{tabular}

DFS: disease free survival; HR: hazard ratio; OS: overall survival; OR: odds ratio; RATS: robotic-assisted thoracic surgery; RR: risk ratio; VATS: video-assisted thoracic surgery; WMD: weighted mean difference; NSCLC: non-small cell lung cancer

principles as anatomical dissection and allows better lymph node dissection ${ }^{[20,21]}$. The main limitations for the wide deployment of RATS are the higher cost of the procedure compared to VATS ${ }^{[22]}$ and logistical issues.

\section{Lymph node dissection and nodal upstaging by RATS, VATS, and open thoracotomy}

Intraoperative lymph node assessment is a critical component in the surgical treatment of NSCLC. Since the development of VATS, there has been controversy concerning lymph node dissection performed by VATS compared to open surgery. Studies have described the feasibility of using VATS to perform complete lymph node dissection and even nodal upstaging, although less commonly than by open surgery. With its intrinsic features, lymph node dissection has been described as easier to perform by RATS than by $\operatorname{VATS}^{[21,23]}$.

Kneuertz et al ${ }^{[24]}$ recently published a propensity-score adjusted comparison of lymph node upstaging by RATS, VATS, and open surgery during lobectomy for a cNo/N1 NSCLC in two centers. Between 2011 and 2018, 911 patients were included (254 RATS, 296 VATS, and 261 open surgery). The overall rate of lymph node upstaging was highest with open lobectomy (21.8\%), followed by RATS $(16.2 \%)$ and VATS $(12.3 \%)(P=$ $0.03)$, with no difference concerning mediastinal N2 upstaging $(P=0.6)$. More nodes were sampled by open surgery (4) than by RATS (3.8) and VATS (3.6) $(P=0.001)$. Finally, on multivariate analysis, the rate of lymph node upstaging was lower for VATS compared to open surgery (OR 0.5, 95\%CI $0.29-0.85, P=0.01$ ) and not different between RATS and open surgery (OR 0.72, 95\%CI 0.44-1.18, $P=0.19$ ). Multiple contemporary studies have reported the same overall long-term survival between VATS lobectomy and open lobectomy, which suggests that there is no decreased long-term survival for patients treated by VATS ${ }^{[25,26]}$. Medbery et al. ${ }^{[27]}$ reported a lower rate of nodal upstaging with VATS than with open surgery $(P<0.001)$, but, in the subgroup of patients operated on in a university hospital, there was no difference between groups $(P=$ 0.08). Recently, Yang et al. ${ }^{[2]}$ reported an absence of difference in the rate of nodal upstaging of patients with clinical T1-T2 N1 MO NSCLC and performed by VATS or open surgery (12\% and 10.5\%, respectively, $P=0.41)$. The five-year overall survival was not different between the two groups $(48.6 \%$ and $48.7 \%$, respectively, $P=0.76$ ). With RATS, the rate of nodal upstaging was not different compared to open surgery, and higher than with VATS ${ }^{[20,21]}$. 


\section{Main results of meta-analysis and systematic reviews according to lobectomy performed by}

\section{RATS, VATS, or open surgery}

$\mathrm{Ng}$ et al. ${ }^{[13]}$ published the latest and most extensive systematic review and meta-analysis in 2019 comparing VATS to open thoracotomy, VATS to RATS, and also multiport and uniport VATS. They included 138 studies and 7 randomized controlled trials with 369,793 patients. They analyzed short-term outcomes such as complications, mortality, and oncologic quality criteria with lymph node dissection and long-term outcomes. They also analyzed functional data with pain, quality of life, pulmonary function, and costeffectiveness. They reported a lower complication rate with VATS lobectomy than with open lobectomy (OR $0.64,95 \% \mathrm{CI} 0.59-0.71, P<0.001)$, and no difference in mortality rate (OR $0.78,95 \% \mathrm{CI} 0.56-1.07, P=0.12$ ). The rate of nodal upstaging was lower with VATS than with open surgery (OR $0.71,95 \% \mathrm{CI} 0.58-0.87$ ), with no difference in the number of lymph nodes resected $(P=0.18)$ or nodal stations explored $(P=0.49)$. They found no difference in the rate of nodal upstaging between VATS and RATS (OR 1.02, 95\%CI 0.85-1.22, $P$ $=0.87)$. Length of hospital stay was shorter after VATS than open surgery, -1.9 days $(95 \% \mathrm{CI}-2.25$ to 1.54 , $P<0.001$ ), but there was no difference between VATS and RATS, -0.16 days (95\%CI 0.81-0.48, $P=0.62$ ). Concerning long-term outcomes, five-year overall survival was improved after VATS lobectomy compared to open lobectomy (OR 1.35, 95\%CI 1.17-1.56, $P<0.0001$ ), with no difference observed in disease free survival (OR 1.15, 95\%CI 0.94-1.40, $P=0.18$ ). There was no difference in five-year overall survival between VATS and RATS (OR $0.79,95 \% \mathrm{CI} 0.47-1.33, P=0.38$ ) or in five-year disease free survival (OR $0.71,95 \% \mathrm{CI}$ 0.44-1.14, $P=0.16$ ). The main results of the reports analyzed in this article are presented in Table 1.

O'Sullivan et al ${ }^{[14]}$ published in 2018 the first systematic review and meta-analysis and concluded that RATS lobectomy significantly improved the short-term outcomes of patients more than VATS or open lobectomy. After RATS lobectomy, compared to open lobectomy, there was an improvement in short-term outcomes, with fewer complications (OR 0.67, 95\%CI 0.58-0.76, $P<0.00001$ ), lower 30-day mortality (OR $0.53,95 \% \mathrm{CI} 0.33-0.85, P=0.08$ ), and shorter length of hospital stay with weighted mean difference (WMD) of -1.4 days ( $95 \% \mathrm{CI}-1.96$ to $0.85, P<0.00001)$, but longer operative times with WMD of $65.56 \mathrm{~min}(95 \% \mathrm{CI}$ 53.66-77.46, $P<0.00001)$. After RATS lobectomy, compared to VATS lobectomy, there was a lower rate of 30-day mortality (OR $0.61,95 \% \mathrm{CI} 0.45-0.83, P=0.001$ ), with longer operative times with WMD of $4.98 \mathrm{~min}$ (95\%CI 2.61-7.36, $P<0.001)$.

Adams et al. ${ }^{[29]}$ in 2014 published one of the first retrospective multicenter comparisons of short-term outcomes after lobectomy performed by RATS, VATS, or open surgery and concluded that RATS was equivalent to VATS for all intraoperative and postoperative outcomes, but allowed better short-term outcomes compared to open surgery. Their main results were lower rates of postoperative blood transfusion (0.9\% vs. $7.8 \%, P=0.002)$, fewer air leaks of more than five days $(5.2 \% v s .10 .8 \%, P=0.05)$, shorter duration of chest tube placement (3.2 days vs. 4.8 days, $P=<0.001$ ), and shorter length of stay (4.7 days vs. 7.3 days, $P<0.001)$. Agzarian et al. ${ }^{[30]}$, Kent et al.$^{[15]}$, and Rajaram et al..$^{[31]}$ concluded that RATS was not superior to VATS for perioperative outcomes. Compared to open surgery, RATS was found superior with fewer perioperative outcomes ${ }^{[32]}$.

Until the publication of O'Sullivan et al. ${ }^{[14]}$, systematic reviews and meta-analyses ${ }^{[32-36]}$ found small significant differences in short-term outcomes between RATS and VATS lobectomy or no difference between these two minimally invasive surgical approaches.

\section{Minimally invasive approaches for locally advanced NSCLC}

Petersen et $a l^{[37]}$ in 2006 were among the first to demonstrate that VATS lobectomy was safe and feasible for selected patients with NSCLC who had received induction chemotherapy or chemoradiotherapy. They reported short-term outcomes with no increase in the number of adverse events after VATS resection and with the same oncologic efficacy. Yang et al ${ }^{[38]}$ reported a propensity score matched analysis, in which survival of patients operated by VATS after induction chemotherapy with or without radiotherapy was 
similar to those who were operated by an open approach $(P=0.56)$. Moreover, 30-day mortality was similar $(P=0.69)$. Veronesi et al ${ }^{[39]}$ reported a multicenter retrospective cohort of patients with stage III NSCLC and operated by a RATS procedure in seven high volume centers. They reported 223 NSCLC, $32 \%$ of which were diagnosed $\mathrm{cN} 2$ preoperatively and $68 \%$ intraoperatively. The rate of conversion to thoracotomy was $9.9 \%$, and the rate of Grade 3 and more complications was $10.3 \%$. For patients who received neoadjuvant chemotherapy, the rate of conversion to thoracotomy was 15\%, the rate of Grade 3 and 4 complications was $12 \%$, and all were resected with Ro margins. Overall 90 -day mortality was $4 \%$ but no patient who received neoadjuvant chemotherapy died. Three-year overall survival was $61.2 \%$, while $60.3 \%$ in the group of patients treated by neoadjuvant chemotherapy $(P=0.6)$.

\section{DISCUSSION}

In this mini-review, we compare short-term outcomes between lobectomy performed by minimally invasive VATS and RATS and lobectomy by open surgery. For several decades, VATS lobectomy has allowed better short-term outcomes compared to open surgery with at least the same long-term oncologic outcomes. These results were obtained by systematic review and meta-analysis of retrospective series and of some randomized controlled trials.

Before discussing the reported results, the common points and differences among RATS, VATS, and open approaches are clarified. Together, there are three surgical approaches but two surgical feelings and two resection concepts for lung lobectomy.

Regarding surgical feelings, also called haptic - force and tactile - feedback, compared to open surgery, VATS allows us to feel each tension exerted on the tissues, because we directly manipulate the tissue, lung, lymph nodes, and other structures. Conversely, the robotic platform is a robotic device guided by the surgeon using a digital interface. With the Da Vinci platform, we do not receive sensitive feedback in our hands. This lack of feedback is one of the criticisms made of this surgical tool. However, "when one feeling is lacking, we say that another develops". Thus, surgeons who can no longer rely on touch see their eyes sharpen, becoming an extension of their hands. With training, they learn and feel the tension exerted on the tissue by seeing the latter exerted on the tissue, allowing them to exceed this limit. The surgeon assistants who expose and retract the lung will also help the operator surgeons, because they can feel the exerted tension on lung by the robot and thus the operator. Nevertheless, robotic surgery industries are studying haptic feedback, but each robotic system is different, thus each research system is different. Moreover, it is important to first understand how we perceive force and tactile information, because it will affect the way we design haptic displays ${ }^{[40]}$.

Regarding resection concepts, compared to VATS and the anterior approach - e.g., fissureless technique RATS allows us to mimic open surgery techniques. The robotic platform allows thoracic surgeons to perform a lobectomy, as they would have done using an open approach. Conversely, the fissureless approach in VATS lobectomy is a necessary adaptation of a surgical technique.

In 2016, Bendixen et al. ${ }^{[18]}$ published a randomized controlled trial comparing lobectomy by VATS and by anterior muscle sparing thoracotomy. For VATS, the authors observed less pain on Postoperative Day 1 $(P=0.0012)$ and during the year after resection $(P<0.0001)$, as well as better quality of life according to EuroQol 5 Dimensions (EQ5D) $(P=0.014)$. Nevertheless, they found no difference between VATS and thoracotomy for postoperative Grade 3 and 4 adverse events, and quality of life according to the European Organisation for Research and Treatment of Cancer 30-item quality of life questionnaire (QLC-C30) $(P=$ 0.13). More recently, the first results of the randomized controlled VIOLET study ${ }^{[41]}$ confirmed better shortterm outcomes after lobectomy by VATS than by open surgery. 
Postoperative complications affect mortality, and major one, as Grades $\geq 3$ according to the Clavien-Dindo classification, have a significant impact on mortality but are rare, with a rate of $4.3 \%$ in the multicenter and retrospective review published by Cao et al. ${ }^{[42]}$. This rate was comparable to outcomes of the CALGB 39802 study, which reported a rate of $7.4 \%$ for Grade $\geq 3$ postoperative complications after a VATS lobectomy ${ }^{[33]}$. In robotic practice, better short-term outcomes were observed after lobectomy by RATS than by open thoracotomy. However, most meta-analyses reported the same short-term outcomes, with as negative points longer operative times and more costly procedures compared to VATS lobectomy ${ }^{[13,15,29-31,34-36,44]}$. Only O'Sullivan et al ${ }^{[14]}$ reported better short-term outcomes with fewer adverse events after lobectomy by RATS compared to VATS in a systematic review with meta-analysis. Nevertheless, some authors reported in retrospective studies a clear benefit of RATS compared to VATS. Reddy et al. ${ }^{[45]}$ recently reported a propensity-matched comparison of lobectomies by surgeons who performed 20 or more VATS or RATS procedures annually. With 838 patients in each group, they observed in the RATS group a lower rate of conversion ( $4.8 \%$ vs. $8 \%, P=0.007)$, a lower rate of 30 -day complications $(33.4 \% v$ s. $39.2 \%, P=0.0128)$, and no difference in mortality rate, but with longer operative times by $25 \mathrm{~min}(P<0.0001)$. They concluded in favor of RATS lobectomy for surgeons performing more than 20 procedures annually. One complication that is less often reported after robotic lobectomy is postoperative anemia requiring blood transfusion. Indeed, robotic surgery allows performing very precise gestures and in particular elective hemostasis during hilar dissection and lymph node resection. For example, Adams et al. ${ }^{[29]}$ reported fewer blood transfusion after a RATS lobectomy compared to a VATS or open lobectomy $(P<0.05)$.

Cost is presented as one of the major drawbacks of RATS ${ }^{[22]}$. In the current context of resource management, Gondé et al. ${ }^{[4]}$ conducted a precise assessment of the economic impact of RATS surgical innovation compared to VATS. RATS lobectomy was found more expensive than VATS lobectomy, and median total costs were $€ 10,972 v s$. $€ 9637(P=0.007)$. Costs related to length of stay were not different $(P$ $=0.061)$, but excessive costs reported in the RATS group were explained by expensive medical devices and supplies used for RATS lung resection $(P=0.004)$. Nevertheless, these authors reported a significantly lower cost of their minimally invasive techniques compared to the mean cost in France $(P=0.001)$. Conversely, VATS was found to be a cost-effective alternative compared to thoracotomy in the randomized controlled trial of Bendixen et al.$^{[47]}$, with a savings of $€ 4267(P<0.001)$. Subramanian et al. ${ }^{[4]}$ reported that, compared to open lobectomy, RATS lobectomy was $13 \%$ more expensive $(P<0.001)$ and VATS lobectomy $2 \%$ less expensive $(P=0.007)$. In their report, they analyzed operating room costs and in-hospital costs from patients operated between 2008 and 2014 in Florida, with data from the Healthcare Cost and Utilization Project Florida State Inpatient Database. Minimal approaches were also associated with improved clinical outcomes compared to open lobectomy $(P=0.016)$, and increased operating room costs were compensated by in-hospital savings. Recently, Kneuertz et al. ${ }^{[49]}$ reported a cost analysis performed at their center. They analyzed data from 697 patients operated by RATS $(n=296)$, VATS $(n=161)$, and open $(n=240)$ for a lobectomy between 2012 and 2017 and performed a propensity score adjustment. Unlike our report ${ }^{[46]}$, and that of Subramanian et al. ${ }^{[48]}$, the overall cost - including operating room costs and in-hospital costs - of the three approaches were similar: RATS $\$ 17,223$, VATS $\$ 17,260$, and open $\$ 18,075(P=0.48)$. Nevertheless, RATS and VATS approaches were associated with higher operating room costs - RATS $\$ 9912$ and VATS $\$ 9491$ - compared to open thoracotomy - $\$ 8698(P=0.001)$. Finally, according to their experience, despite the higher operating room costs calculated for RATS and VATS, it was recovered by postoperative costs reductions associated with improved postoperative outcomes and shorter hospital stay $(P<0.001)$. These three articles ${ }^{[46,48,49]}$ reported higher operating room costs for RATS lobectomy but compensated by improved outcomes compared to thoracotomy. Nevertheless, RATS will always be more expensive, and our goal is to reduce this economic gap. Because patients are well prepared and conditioned within the framework of enhanced recovery protocols, they allow better short-term outcomes for patients operated by thoracotomy and lead to fewer adverse events, shorter length of hospital stay, and logically cost reductions for these patients in 2020 compared to patients operated 5 or 10 years ago. 
Minimally invasive lobectomy performed by VATS or RATS is recommended for early stage NSCLC ${ }^{[1]}$ and the majority of series in this mini-review included stage I NSCLC. Some authors advocate the effectiveness of VATS and RATS for loco-regionally advanced NSCLC. More and more studies have described the effectiveness of a VATS approach for $\mathrm{N}$ positive status ${ }^{[50]}$ and combined resection of a lobe, e.g., with the chest wall ${ }^{[51]}$, the superior vena cava ${ }^{[52]}$ or a sleeve resection ${ }^{[53]}$. For stage IIIA NSCLC, a VATS approach allowed at least the same long-term outcomes compared to thoracotomy, but with better short-term outcomes ${ }^{[38]}$. Extended indications for loco-regionally advanced NSCLC are being explored in robotic thoracic surgery. With the benefits of improved visualization, stability, dexterity, and accuracy, some technical aspects of lobectomy, with complete lymph node dissection, are described as easier to perform by RATS than by VATS ${ }^{[23,54-56]}$, with no difference in long-term outcomes.

Performing minimally invasive surgery using a digital interface has enabled the use of innovative techniques and concepts. The first concept is the use of the simulation tool in the technical learning process. Thus, before performing their first minimally invasive lung resection on a patient, trainee surgeons are able to train on high definition digital simulators close to the reality of the operating room and thus improve their technical skills ${ }^{[57,58]}$. Moreover, with a high-definition CT scanner and 3D modeling, it is possible to precisely plan a complex lung resection such as a segmentectomy on $3 \mathrm{D}$ representation ${ }^{[59]}$. In addition, 3D modeling can be visualized on screen. This augmented reality can be used for liver surgery, for example, but still requires development for lung resection. 3D augmented reality could be used for VATS and RATS surgery and even for open surgery, by using specific glasses. The second concept is the use of safety controls via the robotic platform. Thus, before starting a procedure, security elements are specified to unlock the robot or even the optics of the VATS column to prevent intraoperative accidents.

The majority of the included studies did not use propensity matching, but included heterogeneous groups of patients in terms of disease stage, comorbidity, and surgical approaches. This heterogeneity could potentially mask some results, but reflects "real-life practices in our unit". As such, this mini-review does not provide conclusive evidence regarding the superiority of RATS compared to VATS for short-term outcomes. A randomized controlled trial is required to provide conclusive answers.

\section{CONCLUSION}

Robotic lobectomy could be a valid alternative to open surgery, and provides at least the same short-term outcomes compared to VATS. Based on the findings of recent meta-analyses, lobectomy performed by RATS compared to VATS could allow lower 30-day morbidity and mortality, but with longer operative times and higher surgical costs. According to recent reports, robotic technology seems to be a reasonable alternative to VATS and open surgery. This result must be interpreted with caution, as we cannot exclude an inherent bias related to meta-analyses. A randomized controlled trial with cost analysis and long-term follow-up may be useful to understand the role of robotic technology in thoracic surgery for the benefit of patients with NSCLC.

\section{DECLARATIONS}

\section{Acknowledgements}

The authors are grateful to Nikki Sabourin-Gibbs (Rouen University Hospital) for her help in editing the manuscript.

\section{Authors' contribution}

Collected and selected articles: Montagne F, Baste JM

Participated in manuscript, writing and review: Montagne F, Baste JM

Participated in reviewing: Bottet B, Sarsam M, Mbadinga F, Chaari Z, Rinieri P, Melki J, Peillon C 


\section{Availability of data and materials}

Not applicable.

\section{Financial support and sponsorship}

None.

\section{Conflicts of interest}

Baste JM is proctor for Intuitive Surgical ${ }^{\circ}$ Medtronic $^{\circ}$ and Baxter ${ }^{\circ}$.

\section{Ethical approval and consent to participate}

Not applicable.

\section{Consent for publication}

Not applicable.

\section{Copyright}

(c) The Author(s) 2020.

\section{REFERENCES}

1. Donington J, Ferguson M, Mazzone P, Handy Jr J, Schuchert M, et al. American college of chest physicians and society of thoracic surgeons consensus statement for evaluation and management for high-risk patients with stage I non-small cell lung cancer. Chest 2012;142:1620-35.

2. Postmus PE, Kerr KM, Oudkerk M, Senan S, Waller DA, et al. Early and locally advanced non-small-cell lung cancer (NSCLC): ESMO Clinical Practice Guidelines for diagnosis, treatment and follow-up. Ann Oncol 2017;28:iv1-21.

3. Melfi FMA, Menconi GF, Mariani AM, Angeletti CA. Early experience with robotic technology for thoracoscopic surgery. Eur J Cardiothorac Surg 2002;21:864-8.

4. Rami-Porta R, Wittekind C, Goldstraw P. Complete resection in lung cancer surgery: proposed definition. Lung Cancer 2005;49:25-33.

5. Thomas P, Dahan M, Riquet M, Massard G, Falcoz PE, et al. Pratiques chirurgicales dans le traitement du cancer primitif non à petites cellulesdu poumon. Rev Mal Respir 2008;25:1031-6.

6. Thomas PA. Lymph node dissection during sublobar resection: why, when and how? J Thorac Dis 2018;10:S1145-50.

7. Dahan $\mathrm{M}$, Thomas PA, Riquet M. Cancer primitif non à petites cellules du poumon: pratiques chirurgicales. Société française de chirurgie thoracique et cardiovasculaire. 2008;1-96.

8. Lardinois D, De Leyn P, Van Schil P, Rami-Porta R, Waller D, et al. ESTS guidelines for intraoperative lymph node staging in nonsmall cell lung cancer. Eur J Cardiothorac Surg 2006;30:787-92.

9. Darling GE, Allen MS, Decker PA, Ballman K, Malthaner RA, et al. Number of lymph nodes harvested from a mediastinal lymphadenectomy. Chest 2011;139:1124-9.

10. Ramnath N, Dilling TJ, Harris LJ, Kim AW, Michaud GC, et al. Treatment of Stage III non-small cell lung cancer: diagnosis and management of lung cancer, 3rd ed: American College of Chest Physicians Evidence-Based Clinical Practice Guidelines. Chest 2013;143:e314S-e40S.

11. Detterbeck FC, Lewis SZ, Diekemper R, Addrizzo-Harris D, Alberts WM. Executive summary: diagnosis and management of lung cancer, 3rd ed: American College of Chest Physicians Evidence-Based Clinical Practice Guidelines. Chest 2013;143:7S-37S.

12. McDonald F, De Waele M, Hendriks LEL, Faivre-Finn C, Dingemans A-MC, et al. Management of stage I and II nonsmall cell lung cancer. Eur Respir J 2017;49.

13. Ng CSH, MacDonald JK, Gilbert S, Khan AZ, Kim YT, et al. Optimal approach to lobectomy for non-small cell lung cancer: systemic review and meta-analysis. Innovations 2019;14:90-116.

14. O'Sullivan KE, Kreaden US, Hebert AE, Eaton D, Redmond KC. A systematic review and meta-analysis of robotic versus open and video-assisted thoracoscopic surgery approaches for lobectomy. Interact Cardiovasc Thorac Surg 2018;28:526-34.

15. Kent M, Wang T, Whyte R, Curran TC, Flores R, et al. Open, video-assisted thoracic surgery, and robotic lobectomy: review of a national database. Ann Thorac Surg 2014;97:236-4.

16. Yang CFJ, Sun Z, Speicher PJ, Saud SM, Gulack BC, et al. Use and outcomes of minimally invasive lobectomy for Stage I non-small cell lung cancer in the national cancer data base. Ann Thorac Surg 2016;101:1037-42.

17. Wang Z, Pang L, Tang J, Cheng J, Chen N, et al. Video-assisted thoracoscopic surgery versus muscle-sparing thoracotomy for nonsmall cell lung cancer: a systematic review and meta-analysis. BMC Surg 2019;19:144.

18. Bendixen M, Jørgensen OD, Kronborg C, Andersen C, Licht PB. Postoperative pain and quality of life after lobectomy via videoassisted thoracoscopic surgery or anterolateral thoracotomy for early stage lung cancer: a randomised controlled trial. Lancet Oncol 
2016;17:836-44.

19. Boffa DJ, Kosinski AS, Paul S, Mitchell JD, Onaitis M. Lymph node evaluation by open or video- assisted approaches in 11,500 anatomic lung cancer resections. Ann Thorac Surg 2012;94:347-53.

20. Wilson JL, Louie BE, Cerfolio RJ, Park BJ, Vallières E, et al. The prevalence of nodal upstaging during robotic lung resection in early stage non-small cell lung cancer. Ann Thorac Surg 2014;97:1901-7.

21. Zirafa C, Aprile V, Ricciardi S, Romano G, Davini F, et al. Nodal upstaging evaluation in NSCLC patients treated by robotic lobectomy. Surg Endosc 2019;33:153-8.

22. Park BJ. Cost concerns for robotic thoracic surgery. Ann Cardiothorac Surg 2012;1:56-8.

23. Cerfolio RJ, Ghanim AF, Dylewski M, Veronesi G, Spaggiari L, et al. The long term survival of robotic lobectomy for non-small cell lung cancer: a multi-institutional study. J Thorac Cardiovasc Surg 2018;155:778-86.

24. Kneuertz PJ, Cheufou DH, D'Souza DM, Mardanzai K, Abdel-Rasoul M, et al. Propensity-score adjusted comparison of pathologic nodal upstaging by robotic, video-assisted thoracoscopic, and open lobectomy for non-small cell lung cancer. J Thorac Cardiovasc Surg 2019;158:1457-66.e2.

25. Yang HX, Woo KM, Sima CS, Bains MS, Adusumilli PS, Huang J, et al. Long-term survival based on the surgical approach to lobectomy for clinical Stage I nonsmall cell lung cancer: comparison of robotic, video-assisted thoracic surgery, and thoracotomy lobectomy. Ann Surg 2017;265:431-7.

26. Zirafa CC, Cavaliere I, Ricciardi S, Romano G, Davini F, et al. Long-term oncologic results for robotic major lung resection in nonsmall cell lung cancer (NSCLC) patients. Surg Oncol 2019;28:223-7.

27. Medbery RL, Gillespie TW, Liu Y, Nickleach DC, Lipscomb J, et al. Nodal upstaging is more common with thoracotomy than with VATS during lobectomy for early-stage lung cancer: an analysis from the national cancer data base. J Thorac Oncol 2016;11:222-33.

28. Yang CF, Kumar A, Deng J, Raman V, Lui NS, et al. A national analysis of short-term outcomes and long-term survival following thoracoscopic versus open lobectomy for clinical Stage II non-small-cell lung cancer. Ann Surg 2019.

29. Adams RD, Bolton WD, Stephenson JE, Henry G, Robbins ET, et al. Initial multicenter community robotic lobectomy experience: comparisons to a national database. Ann Thorac Surg 2014;97:1893-8.

30. Agzarian J, Fahim C, Shargall Y, Yasufuku K, Waddell TK, et al. The use of robotic-assisted thoracic surgery for lung resection_a comprehensive systematic review. Semin Thorac Cardiovasc Surg 2016;28:182-92.

31. Rajaram R, Mohanty S, Bentrem DJ, Pavey ES, Odell DD, et al. Nationwide assessment of robotic lobectomy for non-small cell lung cancer. Ann Thorac Surg 2017;103:1092-100.

32. Cao C, Mangranas C, Ang SC, Yan TD. A systematic review and meta-analysis on pulmonary resections by robotic video-assisted thoracic surgery. Ann Cardiothorac Surg 2012;1:3-10.

33. Paul S, Jalbert J, Isaacs AJ, Altorki NK, Isom OW, et al. Comparative effectiveness of robotic-assisted vs thoracoscopic lobectomy. Chest 2015;146:1505-12.

34. Louie BE, Wilson JL, Kim S, Cerfolio RJ, Park BJ, et al. Comparison of video-assisted thoracoscopic surgery and robotic approaches for clinical Stage I and Stage II non-small cell lung cancer using the society of thoracic surgeons database. Ann Thorac Surg 2016;102:917-24.

35. Emmert A, Straube C, Buentzel J, Roever C. Robotic versus thoracoscopic lung resection. Medicine 2017;96:e7633.

36. Wei S, Chen M, Chen N, Liu L. Feasibility and safety of robot-assisted thoracic surgery for lung lobectomy in patients with non-small cell lung cancer: a systematic review and meta-analysis. World J Surg Oncol 2017;15:98.

37. Petersen RP, Pham D, Toloza EM, Burfeind WR, Harpole Jr DH, et al. Thoracoscopic lobectomy: a safe and effective strategy for patients receiving induction therapy for non-small cell lung cancer. Ann Thorac Surg 2006;82:214-8.

38. Yang CFJ, Meyerhoff RR, Mayne NR, Singhapricha T, Toomey CB, et al. Long-term survival following open versus thoracoscopic lobectomy after preoperative chemotherapy for non-small cell lung cancer. Eur J Cardiothorac Surg 2016;49:1615-23.

39. Veronesi G, Park B, Cerfolio R, Dylewski M, Toker A, et al. Robotic resection of Stage III lung cancer: an international retrospective study. Eur J Cardiothorac Surg 2018;54:912-9.

40. Okamura AM. Haptic feedback in robot-assisted minimally invasive surgery. Curr Opin Urol 2009;19:102-7.

41. Lim E, Batchelor T, Shackcloth M, Dunning J, McGonigle N, et al. Study protocol for VIdeo assisted thoracoscopic lobectomy versus conventional Open LobEcTomy for lung cancer, a UK multicentre randomised controlled trial with an internal pilot (the VIOLET study). BMJ Open 2019;9:e029507.

42. Cao C, Louie BE, Melfi F, Veronesi G, Razzak R, et al. Outcomes of major complications after robotic anatomic pulmonary resection. J Thorac Cardiovasc Surg 2020;159:681-6.

43. Swanson SJ, Herndon JE, D’Amico TA, Demmy TL, McKenna Jr RJ, et al. Video-assisted thoracic surgery lobectomy: report of CALGB 39802 - a prospective, multi-institution feasibility study. J Clin Oncol 2007;25:4993-7.

44. Cao C, Manganas C, Ang SC, Yan TD. A meta-analysis of unmatched and matched patients comparing video-assisted thoracoscopic lobectomy and conventional open lobectomy. Ann Cardiothorac Surg 2012;1:16-23.

45. Reddy RM, Gorrepati ML, Oh DS, Mehendale S, Reed MF. Robotic-assisted versus thoracoscopic lobectomy outcomes from highvolume thoracic surgeons. Ann Thorac Surg 2018;106:902-8.

46. Gondé H, Laurent M, Gillibert A, Sarsam OM, Varin R, et al. The affordability of minimally invasive procedures in major lung resection: a prospective study. Interact Cardiovasc Thorac Surg 2017;25:469-75.

47. Bendixen M, Kronborg C, Jørgensen OD, Andersen C, Licht PB. Cost-utility analysis of minimally invasive surgery for lung cancer: a randomized controlled trial. Eur J Cardiothorac Surg 2019;56:754-61. 
48. Subramanian MP, Liu J, Chapman Jr WC, Olsen MA, Yan Y, et al. Utilization trends, outcomes, and cost in minimally invasive lobectomy. Ann Thorac Surg 2019;108:1648-55.

49. Kneuertz PJ, Singer E, D’Souza DM, Abdel-Rasoul M, Moffatt-Bruce SD, et al. Hospital cost and clinical effectiveness of roboticassisted versus video-assisted thoracoscopic and open lobectomy: a propensity score-weighted comparison. J Thorac Cardiovasc Surg 2019;157:2018-26.e2.

50. Hennon MW, Demmy TL. Video-assisted thoracoscopic surgery (VATS) for locally advanced lung cancer. Ann Cardiothorac Surg 2012;1:37-42.

51. Hennon MW, Dexter EU, Huang M, Kane J, Nwogu C, et al. Does thoracoscopic surgery decrease the morbidity of combined lung and chest wall resection? Ann Cardiothorac Surg 2015;99:1929-34.

52. Shao W, Yin W, Wang W, Zhang X, Peng G, et al. Glasses-free three-dimensional endoscopic bronchoplasty, arterioplasty, and angioplasty of the superior vena cava for the radical treatment of right middle upper lung cancer. J Thorac Dis 2016;8:608-11.

53. Lyscov A, Obukhova T, Ryabova V, Sekhniaidze D, Zuiev V, et al. Double-sleeve and carinal resections using the uniportal VATS technique: a single centre experience. J Thorac Dis 2016;8:S235-41.

54. Turner SR, Latif MJ, Park BJ. Robotic assisted VATS lobectomy for loco-regionally advanced non-small cell lung cancer. Video Assist Thorac Surg 2017;2.

55. Chen S, Geraci TC, Cerfolio RJ. Techniques for lung surgery: a review of robotic lobectomy. Expert Rev Respir Med 2018;12:315-22.

56. Baste JM. Locally advanced N2 non-small cell lung cancer and the robotic platform: are we asking the right question? J Thorac Dis 2019;11:S1184-5.

57. Gerull W, Zihni A, Awad M. Operative performance outcomes of a simulator-based robotic surgical skills curriculum. Surg Endosc 2019; Epub ahead of print [PMID: 31732857 DOI: 10.1007/s00464-019-07243-6]

58. Bric JD, Lumbard DC, Frelich MJ, Gould JC. Current state of virtual reality simulation in robotic surgery training: a review. Surg Endosc 2016;30:2169-78.

59. Soler L, Nicolau S, Pessaux P, Mutter D, Marescaux J. Real-time 3D image reconstruction guidance in liver resection surgery. Hepatobiliary Surg Nutr 2014;3:73-81. 